\title{
The Effect of Electronic Word of Mouth (e-WOM) Advertising on the Sports Customers' Purchase Intention with Emphasis on the Mediator Role of Consumer's Involvement
}

Habibeh Ghate ${ }^{1}$, Mahboub Sheikhalizadeh ${ }^{2}$

1. Habibeh Ghate, (M.A Student) Islamic Azad University, Ahar Branch, Iran

2. Mahboub Sheikhalizadeh, (Ph.D) Islamic Azad University, Ahar Branch, Iran

\section{ARTICLE INFO}

Received September 2018

Accepted September 2019

\section{KEYWORDS:}

Electronic Word of Mouth (eWOM) Advertising

Digital Marketing

Purchase Intention

Consumer Involvement

Sport Customers

CITE:

Ghate, Sheikhalizadeh, The Effect of Electronic Word of Mouth (eWOM) Advertising on the Sports Customers' Purchase Intention with Emphasis on the Mediator Role of Consumer's Involvement, Research in sport management \& motor behavior, 2020: 9(18)111-126

\section{ABSTRACT}

The present study aimed to investigate the effects of electronic word of mouth (e-WOM) advertising on the sports customers' purchase intention with emphasis on the mediator role of consumer's involvement. 270 sport customers voluntarily filled out the Bambauer-Sachse and Mangold electronic word of mouth advertising (2011), McQuarrie's consumer involvement (1992) and the Diallo (2012) and Park et al purchase intention (2008) questionnaires. Structural equation modeling (SEM) in software Lisrel 8.51 was used to analyze the data. The results showed that the electronic word of mouth advertising had a significant direct effect on the purchase intention $(\gamma=0.22 ; p<0.05)$ and the consumer involvement $(\gamma=0.70 ; p<0.01)$. The Findings prove the positive moderation role of involvement on the relationship between electronic word of mouth (e-WOM) advertising and purchase intention. According to results of model analysis the modified model had good fit (CFI=0.94; RMSEA $=0.077$; $\chi 2 / d f=2.60$ ). In conclusion, we can say that electronic word of mouth (e-WOM) advertising can have a great impact on the individual knowledge about products and consumer involvement in them, and it can thus affect consumers' purchase intention by provision of a large volume of information in a short time. 


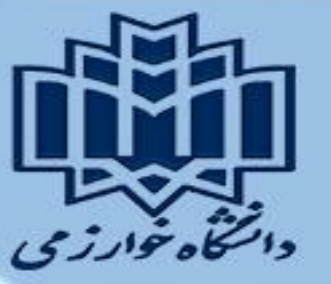

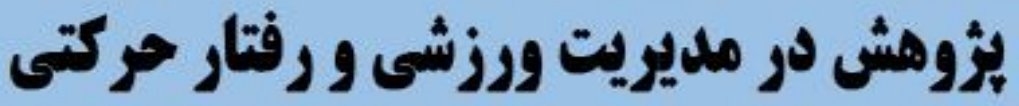

\section{تأثير تبليغات دهانبهدهان الكترونيكى بر قصل خريد مشتريان ورزشى با تاكيل بر نقش مياذجى در كيرى ذهنى مصرف كننله}

\author{
حبيبه قطعى'، محبوب شيخعلى زاده* \\ ا. دانشجوى كارشناسى ارشد، كروه تربيت بدنى و علوم ورزشى، دانشخاه آزاد اسلامى، واحد اهر، ايران

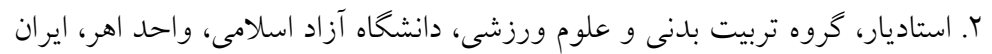

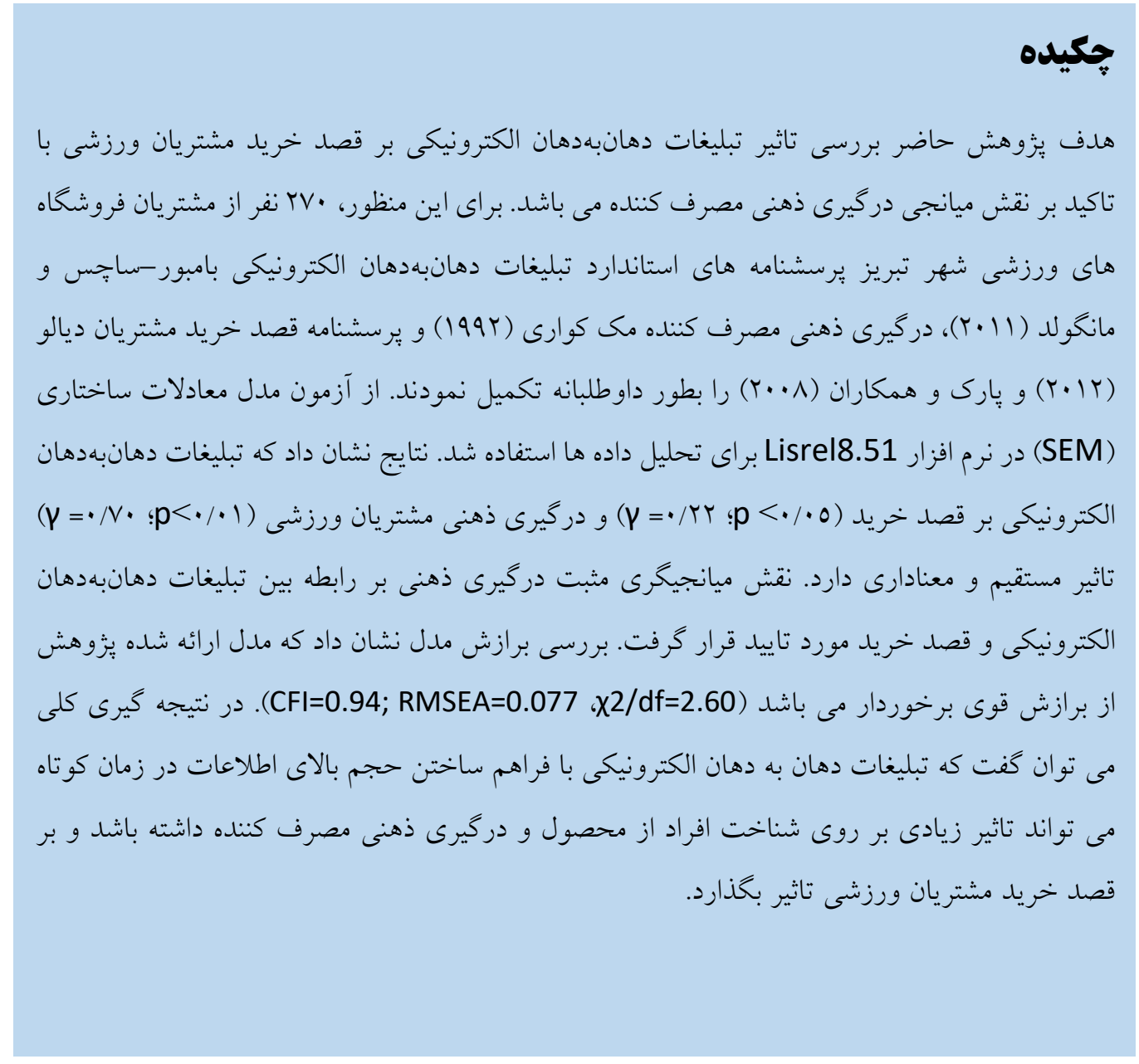
اطألاعات مقاله:

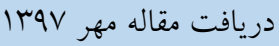
يذيرش مقاله شهريور 1هس|
*ونويسنده مسئول:
m-sheykhalizadeh@iau-ahar.ac.ir
وازٔه هاى كليلهى:
تبليغات توصيه ایى الكترونيكى ليك
بازاريابى ديجيتال
در گيرى ذهنى مصرف كننده

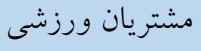

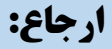
قطعى، شيخعلى زاده. تأثير تبليغات دهانبهدهان الكترونيكى بر قصد خريد مشتريان ورزشى با تاكيد بر نقش ميانجى درگيرى ذهنى مصرف كننده. يُزوهش در مديريت ورزشى

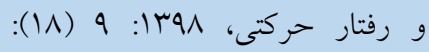




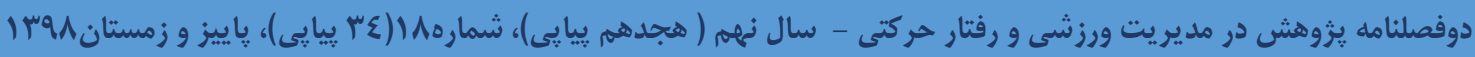

امروزه با افزايش رقابت در بازار محصولات و تجهيزات ورزشى و تلاش شركتها و برندهاى ورزشى در سطح كلان و فروشگاههاى ورزشى در سطح خرد، بيش از بيش، شيوههاى جذب و نخهاشت مشترى نمود بيدا كرده است. مديران فروشگاههاى ورزشى تلاش مى كنند با معرفى محصولات خود در صفحات اينترنتى و قابليتهاى نظرسنجى، كم و كيف محصولات خود را اطلاع رسانى نموده و با تبليغات دهانبهدهان الكترونيكى موجبات افزايش قصد خريد را در مشتريان فراهم آورند. به عقيده محققين، شركتها مىتواند با به كاركيرى بازاريابى دهانبهدهان كه يكى از كار آمدترين و مؤثرترين

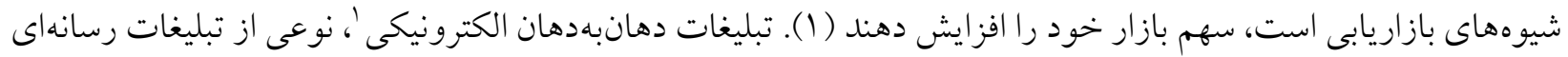
با استفاده از انواع وبسايت كه در آنها بيشترين دسترسى به عقايد و تجديدنظرهاى مصرفكنندكان آنلاين و آمارها وجود دارد (Y). در شيوه تبليغاتى دهانبهدهان الكترونيكى افراد تمايل دارند درباره تجربيات گوناكون خود با يكديكر صحبت كنند و با مبادله توصيه هاى مثبت يا منفى راجع به كالا يا خدمت خاص، خطريذيرى خريد خود را به بايين ترين حد ممكن رسانده و بهترين و مناسبترين گزينه را انتخاب كنند (r). لذا با گسترش كانالهاى ارتباطى الكترونيكى و ديجيتال مانند شبكه هاى اجتماعى، تلفن همراه و اينترنت در سالهاى اخير و افزايش روز افزون كاربران اين رسانهها، مرزهاى فيزيكى از بين رفته است و در بستر ايتترنت، مصرف كنندكان مى توانند نظرت شان را ارسال كنند، توضيح و تفسير (كامنت) بخذارند و محصولات را در وبلاكى ها، اتاق هاى بحث، وب سايت هاى بازنخرى، گروه هاى خبرى و سايت هاى شبكه هاى اجتماعى بازنخرى و ارزيابى كنند (ع). افراد مىتوانند با استفاده از اين رسانهها به فعاليتهايى جون جستجوى اطلاعات مورد نياز خود برداخته و در زمان تصميم گيرى براى خريد با ديخران نيز مشورت كنند. يزوهش هاى انجام شده در خصوص بازاريابى دهان به دهان مى دهد كه ارتباطات دهان به دهان موثرتر از ارتباطات از طريق ساير منابع مانند توصيه هاى مطالب مهم روزنامه يا آكهى است؛ زيرا اين طور درى شده كه اطلاعات مقايسه اى معتبرى را ارائه مى دهد (0)؛ بنابراين در محيط هاى رقابتى امروزى، لازم است علاوه بر مشتريان ورزشى، مديران و صاحبان فروشگاههاى تجهيزات ورزشى نيز از اين فرصت بالقوه استفاده كرده و با استفاده از تبليغات دهانبهدهان الكترونيكى از

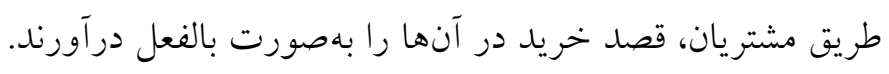
در بازاريابى نسل ع يا بازاريابى نوين، علاوه بر ايجاد تبليغات الكترونيكى و معرفى محصول (بهصورت نرمافزارى مانند

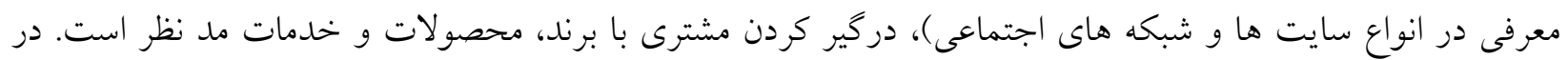
اين بين توانايى درگير كردن ذهن مصرف كننده با محصول ارائهشده مىتواند در بيشبرد اهداف بازاريابى و فروش مؤثر باشد. دركيرى ذهنى ب بعنوان وابستخى درى شده يك شخص از يك هدف بر اساس نيازهاى اساسى، ارزشها و علائق تعريف مى شود (7). در گيرى ذهنى مصرف كننده تشريح مى كند كه جرا مصرف كنند گان به برخى از فعاليت هاى خريد بيشتر از ديكر فعاليت ها علاقمندند و جُخونه مصرف كنند كان بيام هاى متفاوتى را در طول ارتباطات خريد دريافت مى

\footnotetext{
1 - Electronic Word of Mouth (e-WOM)
}

2 - Involvement

https://jrsm.khu.ac.ir/ 


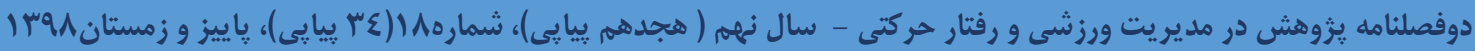

كنند (V). براى درى رفتار مصرف كننده، شناخت ساختار دركيرى ذهنى مصرف كننده بسيار با اهميت است؛ بهخصوص كص وقتى مصرف كنندگان در بازار لوازم و تجهيزات ورزشى با تنوع وسيعى از برندها با قيمتها و كيفيتهاى متفاوت روبرو مىشوند. بسيارى از محققين متغير درگيرى ذهنى مصرف كننده را بهعنوان مهمترين متغير در ادبيات بازاريابى به خاطر ارزش بالاى بيشكويى آن در رفتار خريد در نظر مى گيرند كه مىتواند در قصد خريد تأثير به سزايى داشته باشد (••(1)؛ بنابر اين مفهوم دركيرى ذهنى نقش مهمى در تفسير رفتار مصرف كننده امروزى ايفا مى كند. اهميت بررسى مفهوم دركيرى

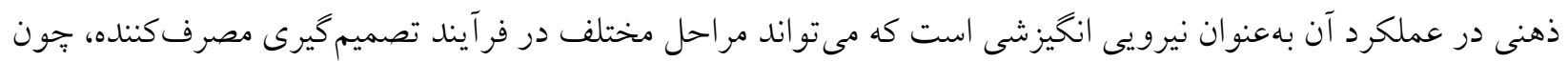
كستردكى جستجوى اطلاعات، طول مدت فر آيند تصميم گيرى، شكل گيرى باورها، نحرشها و عقايد، همجنين بيامدهاى رفتارى جون رفتارهاى جستجوى متفاوت، تغيير برند، تعهل به برند، وفادارى به برند، استفاده مكرر از محصول و لذت از خريد را توصيف كند (11). شركتها قبل از تهيه خطمشىهاى بازاريابى خود، به شناخت مصرف كنند كان و فرآيندهاى تصميم كيرى خريد آنها نياز دارند، درى عوامل مؤثر بر تصميم خريد مصرف كننده و درى فر آيندهاى كلى كه از طريق آن اشخاص رفتار مى كنند و در نهايت درى تصميماتى كه اتخاذ مى كنند، يك كام مهم در ايجاد برنامههاى بازاريابى و در نهايت كسب مزيت رقابتى است. خلاصه ایى از نتايج تحقيقات انجام شده نشان دهنده رابطه بين دركيرى ذهنى به عنوان

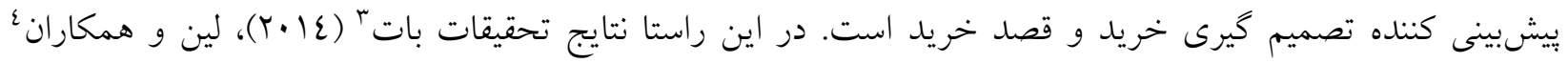

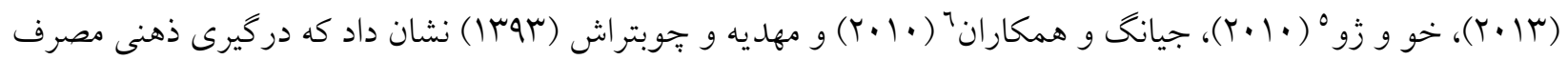

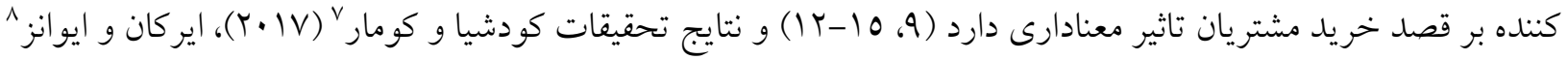

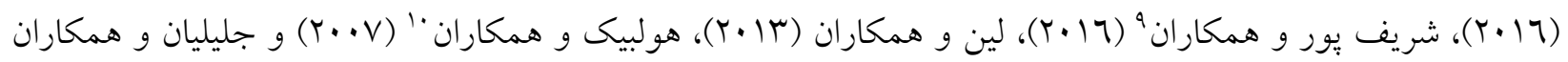
(1) (1) حاكى از آن بود كه تبليغات دهانبهدهان الكترونيكى بر قصد خريد مصرفكنندكان تاثير مثبت و معنادارى دارد (ع)، •Y-T (1). همجنين شهابى يوسف و همكاران (Y) (Y) در يزوهش خود به اين نتيجه رسيدند كه نخرش به تبليغات دهان به دهان الكترونيكى بر قصد خريد مشتريان تاثير مثبت و معنادارى دارد (Y). با توجه به اينكه ادراك مشترى از تبليغات بر انتخاب محصول و قصد خريد آنها موثر است، به نظر مى رسد با كسترش شبكه هاى اجتماعى و بيام رسان هاى داخلى و خارجى در كشور و بخصوص در كلان شهر تبريز، شكل سنتى و محدود تبليغات، به حالت تبليغات توصيه ای الكترونيكى و كسترده در بين اكثريت مردم تغيير يابد و احتمالاً اين تغيير در شكل تبليغات، منجر به تغيير درگيرى ذهنى مشترى خواهد شد، در نتيجه احتمال مى رود هر اندازه بيام هاى دهان به دهان

\footnotetext{
3 - Butt

4 - Lin et al

5 - Xue \& Zhou

6 - Jiang et al

7 - Kudeshia \& Kumar

8 - Erkan \& Evans

9 - Sharifpou

10 - Hollebeek et al
}

https://jrsm.khu.ac.ir/ 


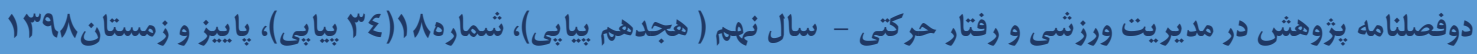

الكترونيكى مثبت يا منفى بين مشتريان ورزشى در شبكه ها و فضاهاى مجازى رد و بدل شود، منجر به ايجاد جارجوب هاى ذهنى مثبت و منفى خواهد شد و در نتيجه قصد خريد مشتريان ورزشى را تحث تاثير قرار خواهد داد. لذا سوالى كه براى محققين بزوهش حاضر مطرح كرديد اين است كه از ديد گاه مشتريان ورزشى شهر تبريز، تبليغات دهان به دهان الكترونيكى بر قصد خريد مشتريان تاثير مى كذارد؟ و اينكه درگيرى ذهنى مصرف كننده در رابطه ميان تبليغات دهان به دهان الكترونيكى با قصد خريد مشتريان نقشى ايفا مى كند؟ بررسى تحقيقات انجام يافته نشان مى دهد كه متغيرهاى مورد نظر به صورت مجزا مورد بررسى قرار كرفته اند و ارتباط بين سه متغير مورد بررسى بصورت همزمان مورد بررسى قرار نخرفته است. همجنين نقش ميانجى متغير دركيرى ذهنى مصرف كننده در تحقيقات حوزه بازاريابى ورزشى مورد مطالعه قرار نخرفته است، لذا با توجه به ادبيات نظرى مطرح شده برهي و تحقيقات مورد مطالعه، مدلى در ارتباط به متغيرهاى تحقيق تدوين شده است و مدل مفهومى تحقيق (شكل ( ) به شرح زير مطرح مى شود:

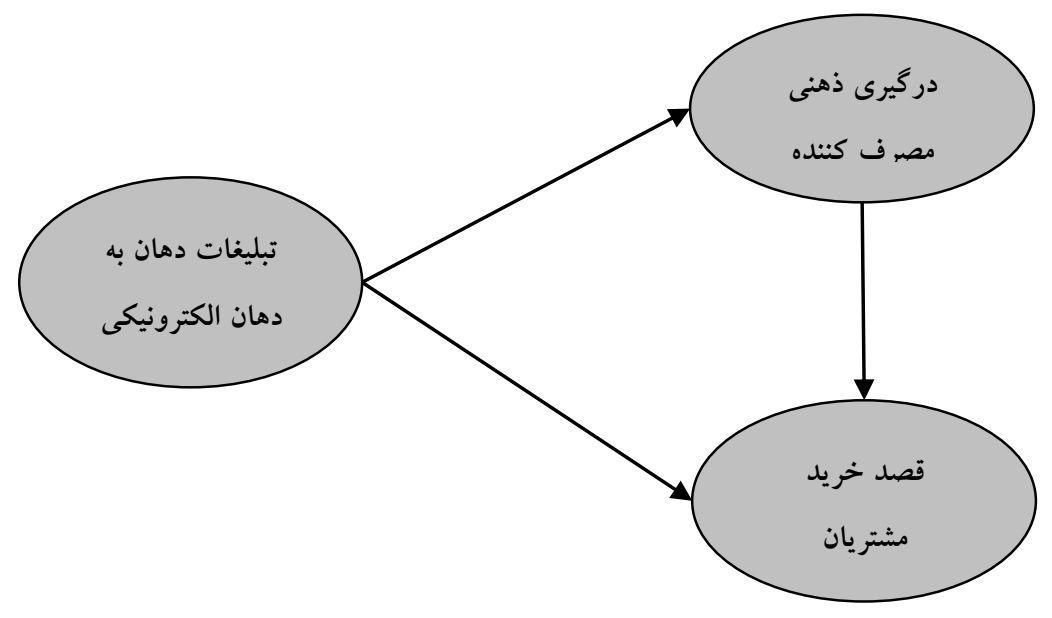

شكل ا: مدل مفهومى تحقيق

روششناسى بثوهش

يزوهش حاضر بر اساس هدف تحقيق در بررسى رفتار مشتريان و مصرف كنندگان محصولات ورزشى در صنعت خردهروشى، از نوع يزوهش هاى كاربردى است. روش تحقيق مورد استفاده در اين بزوهش از نوع توصيفى ـ همبستخى است. جامعه آمارى اين يزوهش را كليه مشتريان و مصرفكنند كان محصولات (كالاها) ورزشى در شهر تبريز تشكيل مىدهند. همجنين به دليل نامعلوم بودن تعداد افراد جامعه، جهت تعيين حجم نمونه نيز از جدول نمونه كيرى كرجسى و موركان استفاده شد و حجم نمونه عیى نفر برآورد شد و همين تعداد برسشنامه با مراجعه به فروشگاه هاى ورزشى شهر

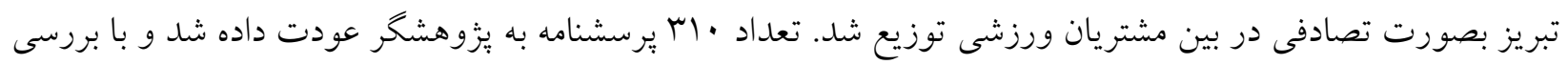




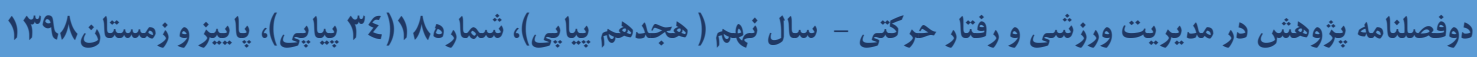

يُرسشنامهاى بدون نقص، تحليل داده ها با استفاده از •rV يرسشنامه بدون ايراد انجام شد. براى جمع آورى داده ها از

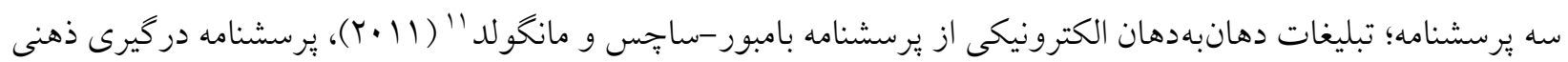

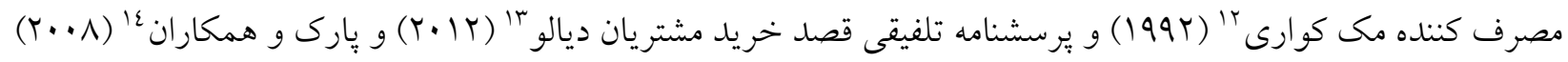

استفاده شد (YYTO)

از يرسشنامه بامبور -ساجِس و مانحولد (111) براى جمع آورى داده ها در خصوص تبليغات دهانبهدهان الكترونيكى

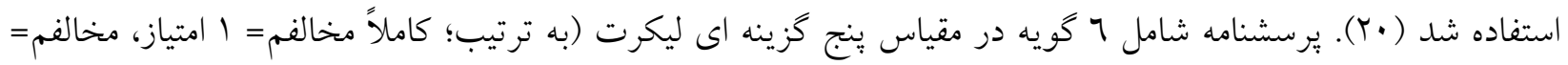

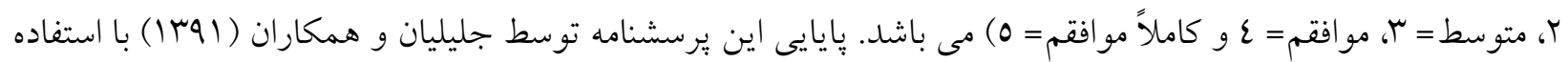

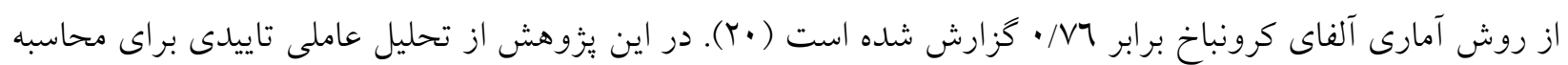
بارهاى عاملى مولفه هاى برسشنامه تبليغات دهانبهدهان الكترونيكى استفاده شد و نتايج نشان داد كه بارهاى عاملى تمام

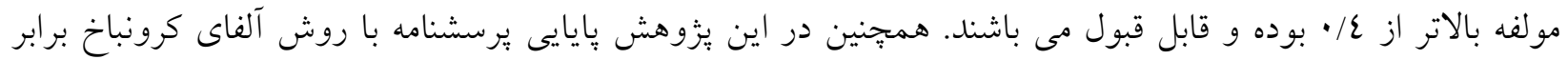

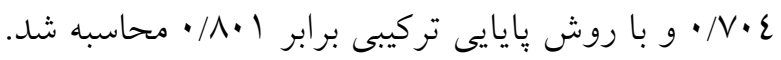

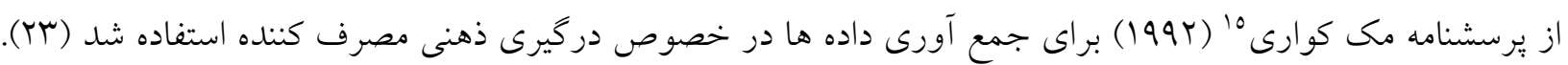

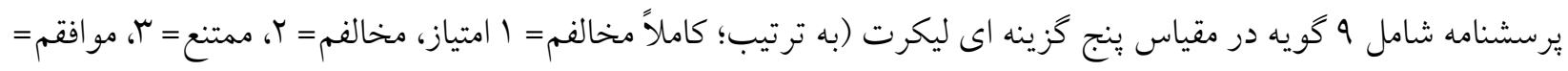

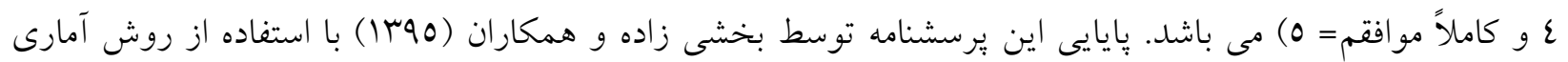

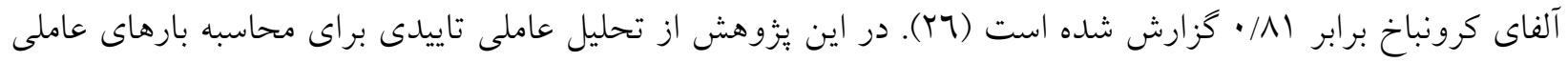
مولفه هاى برسشنامه در گيرى ذهنى مصرف كننده استفاده شد و نتايج نشان داد كه بارهاى عاملى تمام مولفه بالاتر از ع/ • بوده و قابل قبول مى باشند. همجنين در اين يُزوهش بايايى يرسشنامه با روش آلفاى كرونباخ برابر ع71/· و با روش

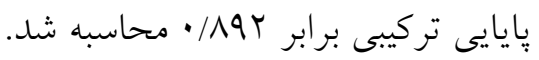

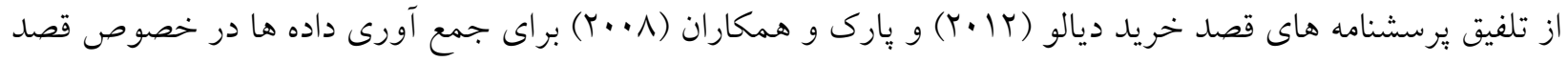
خريد مشتريان استفاده شد (ع)، TO). يرسشنامه شامل I كويه در مقياس ينج گزينه اي ليكرت (به ترتيب؛ كاملاً مخالفم=

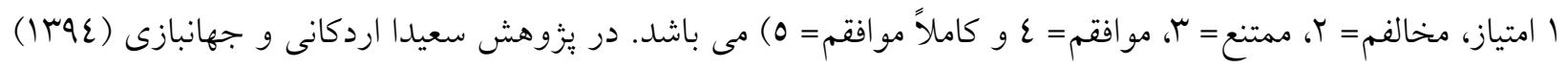

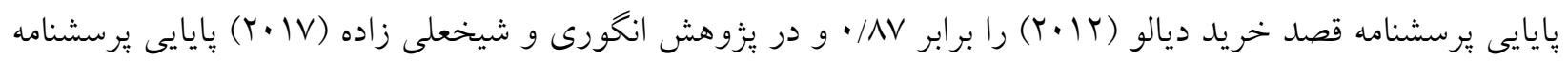

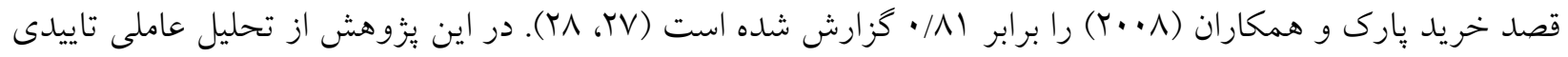
براى محاسبه بارهاى عاملى مولفه هاى برسشنامه قصد خريد مشترى استفاده شد و نتايج نشان داد كه بارهاى عاملى تمام مولفه بالاتر از ح/• بوده و قابل قبول مى باشند. همجنين در اين يزوهش يايايى يرسشنامه با روش آلفاى كرونباخ برابر

\footnotetext{
11 - Bambauer-Sachse \& Mangold

12 - McQuarrie

13 - Diallo

14 - Park et al

15 - McQuarrie
}

https://jrsm.khu.ac.ir/ 


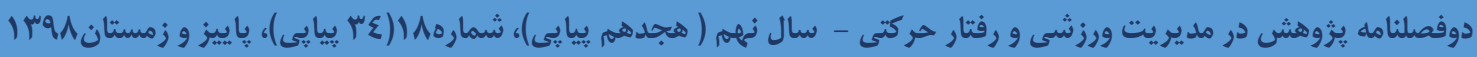

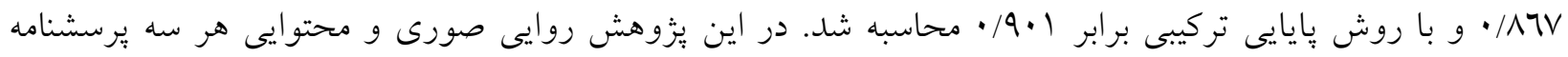
توسط ينج نفر از اساتيد مديريت ورزشى مورد تاييد قرار گرفت. براى ارزيابى رابطه عامل ها (متغيرهاى مكنون) با كويه ها (متغيرهاى مشاهده شده) از تحليل عاملى تاييدى (CFA)، براى ارزيابى مدل ساختارى (ارتباط بين متغيرهاى مكنون)

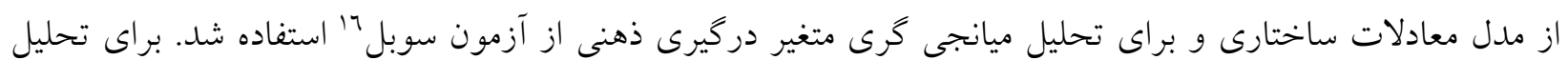
داده ها از نرم افزارهاى SPSS نسخه سب، نرم افزار Sisrel8.51 و نرم افزار Smart PLS استفاده شد.

\section{يافتهاى يخوهش}

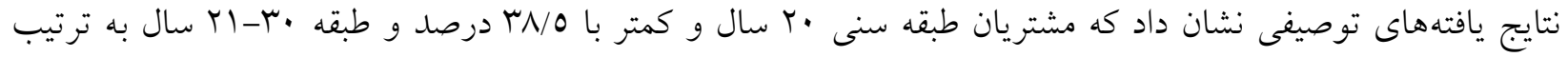
داراى بيشترين فراوانى بودند. بيشترين فراو انى جنسيت مربوط به مشتريان زن با VO/Y درصد است. مشتريان داراى مدرى

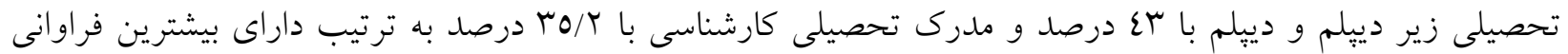

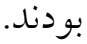

جهت تعيين نرمال بودن داده ها از آزمون كلموكروف-اسميرنف استفاده شد. نتايج اين آزمون نشان داد كه سطح معنى دارى در هر سه متغير تبليغات دهان به دهان الكترونيكى، دركيرى ذهنى و قصد خريد سطح معنى دارى كمتر از 0 •/

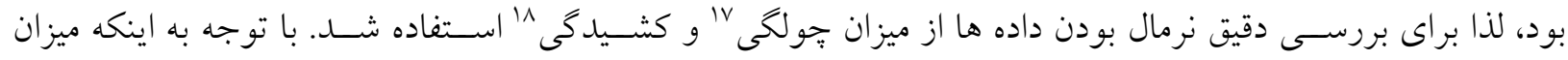

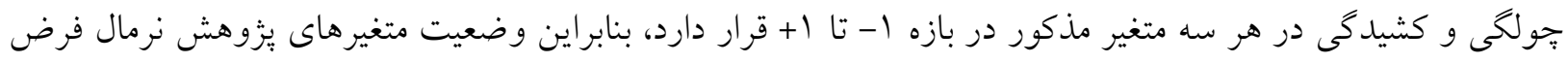

\section{آزمون هاى KMO و بارتلت}

ييش از اجراى تحليل عاملى لازم است مفروضه هاى زير رعايت شود: براى تعيين كفايت تعيين حجم نمونه از آزمون كيسر - مير- الكين (KMO) استفاده شد. با توجه به اينكه مقدار براى هر سه ابزار مورد استفاده بزرگ تر از ح/· بدست آمد (جدول ()، بنابراين مى توان تحليل عاملى را انجام داد.

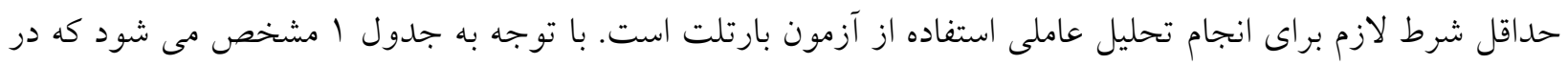
هر سه مورد آزمون بارتلت معنادار بوده، بنابراين حداقل شرايط لازم براى انجام تحليل عاملى وجود دارد.

جدول ا. نتايج آزمون KMO و بارتلت

16 - Sobel Test

17 - Skewness

18 - Kurtosis

https://jrsm.khu.ac.ir/ 


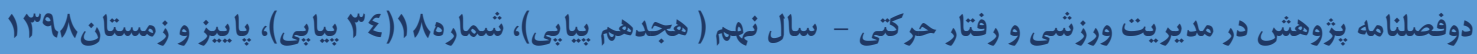

\begin{tabular}{|c|c|c|c|c|}
\hline \multicolumn{3}{|c|}{ مقادير به دست آمده } & \multirow[b]{2}{*}{ مقدار مناسب } & \multirow[b]{2}{*}{ شاخص } \\
\hline قصد خريد & دركيرى ذهنى مصرف & تبليغات دهانبهدهان & & \\
\hline$\cdot / A \cdot T$ & $\cdot / \wedge 91$ & $\cdot / \Lambda T V$ & بالاتر از 7/. & الكين (KMO - مير- \\
\hline$\cdot \cdots$ & $\cdot \cdots$ & $\cdot \cdots$ & كمتر از 0.٪ & بارتلت ب \\
\hline مناسب & مناسب & مناسب & ون ان & نتيجه \\
\hline
\end{tabular}

\section{آزمون هاى يايايى و روايى}

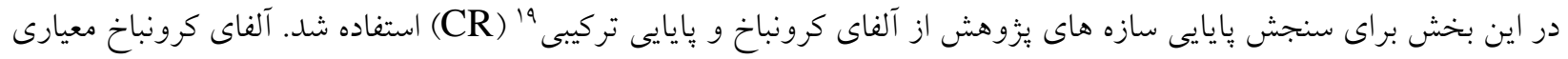

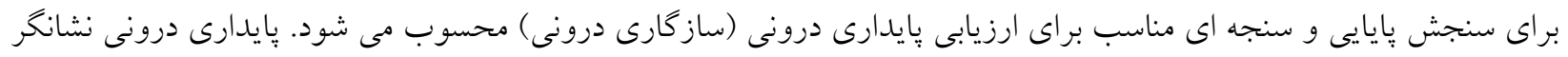

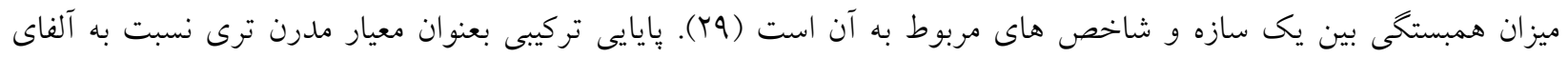

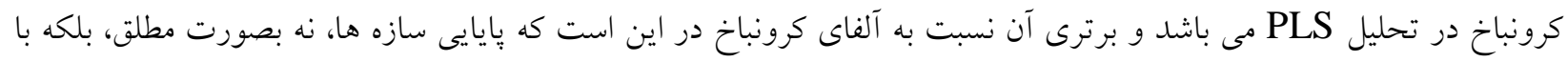

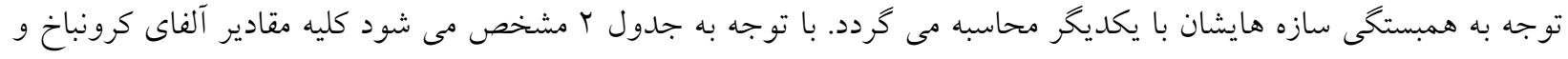

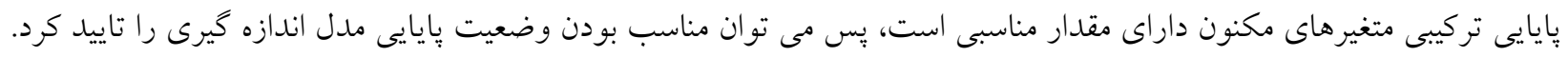

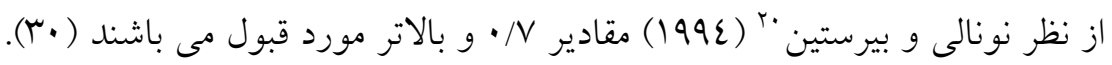

جدول r. سنجش بايايى سازه هاى يُوهش

\begin{tabular}{|c|c|c|}
\hline بِايايى تركيبى (CR) & آلفاى كرونباخ & متغيرهاى مكنون \\
\hline$\cdot / \wedge \cdot 1$ & $\cdot / v \cdot \varepsilon$ & تبليغات دهانبهدهان الكترونيكى \\
\hline •/А९T & $\cdot / \Lambda 7 \varepsilon$ & درگيرى ذهنى مصرف كننده \\
\hline$\cdot / 9 \cdot 1$ & $\cdot / 1 \mathrm{TV}$ & قصد خريد \\
\hline
\end{tabular}

با توجه به مدل اندازه گيرى، روايى همخراى متغيرهاى تحقيق مورد ارزيابى قرار گرفت. روايى همخراى متغيرها به اين

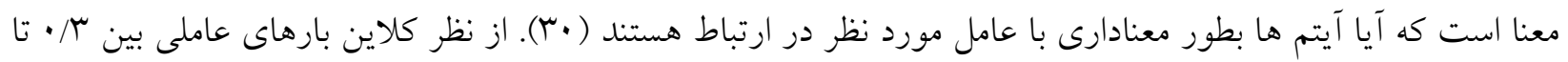

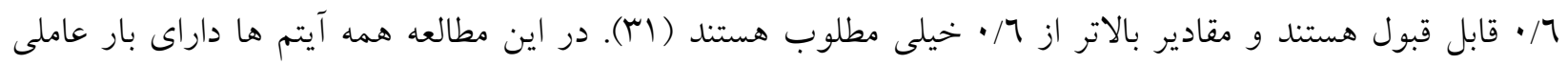
معنادارى بودند و بويزه مقادير t بزركتر از 1/97 بود كه در سطح معنادارى 0٪/ • معنادار مى باشند. تمامى آيتم ها داراى بار عاملى بيشتر از ع/• بودند كه نشان دهنده روايى همخراى قابل قبول متغيرهاى تحقيق مى باشد. همجنين از معيار

19 - Composite Reliability

20 - Nunnally \& Bernstein

https://jrsm.khu.ac.ir/ 
AVE براى ارزيابى روايى همخرا استفاده شد. AVE نشان دهنده ميانخين واريانس به اشتراى كذاشته شده بين هر سازه با شاخص هاى خود است (Yr). در جدول r مقادير AVE توسط نرم افزار Smart PLS براى هر متغير مكنون محاسبه شده است. با توجه به مقادير AVE مشخص مى شود كه متغيرهاى مكنون مورد مطالعه داراى روايى همخراى بالايى برخوردار هستند؛ به عبارت ديخر همبستگى بالايى بين هر سازه با شاخص هاى خود وجود دارد و در نتيجه مدل هاى اندازه گيرى از برازش قابل قبولى برخوردار مى باشند.

جدول r. ضرايب AVE متغيرهاى مكنون

\begin{tabular}{|c|c|}
\hline ميانخين واريانس استخراج شده (AVE) & متغيرهاى مكنون \\
\hline$\cdot / \varepsilon \cdot r$ & تبليغات دهانبهدهان الكترونيكى \\
\hline$\cdot / \varepsilon \wedge 1$ & درگيرى ذهنى مصرف كننده \\
\hline$\cdot / 7 \cdot r$ & قصد خريد \\
\hline
\end{tabular}

آزمون مدل اندازه كيرى

قبل از انجام آزمون مدل ساختارى، براى اطمينان از صحت مدل اندئ اندازه گيرى، از تحليل عاملى تاييدى (CFA) استفاده شد. تحليل عاملى مرتبه دوم براى متغيرهاى برونزا (تبليغات دهانبهدهان الكترونيكى) و متغيرهاى درونزا (در گيرى ذهنى مصرف كننده و قصد خريد مشترى) انجام يذيرفت. نتايج نشان داد كه شاخص هاى برازش براى تمامى متغيرهاى مدل

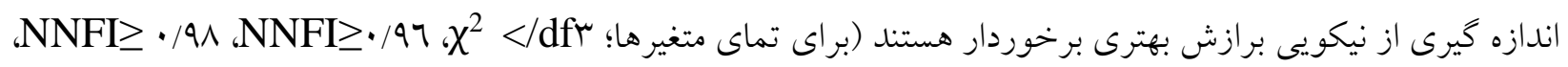
. (جدول) (CF $\geq \cdot / 91$

\begin{tabular}{|c|c|c|c|c|c|c|c|}
\hline CFI & NNFI & NFI & RMSEA & $\chi^{2} / \mathbf{d f}$ & آزادى درجه & $\chi^{2}$ & متغيرها \\
\hline.$/ 99$ &.$/ 91$ &.$/ 97$ & .1 .49 & $1 / 21$ & 9 & $I T / N$. & تبليغات دهانبهدهان \\
\hline.$/ 91$ & $\cdot / 91$ & $\cdot / 9 \mathrm{~V}$ & .1 .7$. & $1 / 97$ & TV & or & دركيرى ذهنى مصرف \\
\hline 1 & $\cdot / 99$ &.$/ 99$ & .1 .0$. & $1 / 77$ & 9 & $12 / 97$ & قصد خريد \\
\hline
\end{tabular}

آزمون مدل ساختارى

21 - Average Variance Extracted (AVE)

https://jrsm.khu.ac.ir/ 
از تكنيك مدل معادلات ساختارى براى آزمون ارتباط هاى علّى بين متغيرهاى مكنون استفاده شد. نتايج مدل ساختارى نشان داد كه شاخص هاى محاسبه شده برازش مدل بهترى را ارائه مى دهند:

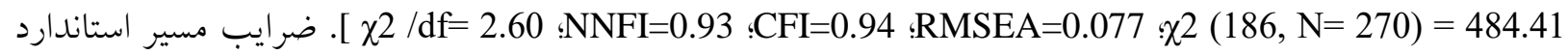
شده مى تواند به عنوان ضريب رگرسيون استاندارد شده براى بررسى اثر يك متغير مكنون در ارتباط با ديخر متغير مورد استفاده قرار كيرد. نتايج اين مطالعه نشان داد كه تبليغات دهان به دهان الكترونيكى بر دركيرى ذهنى مصرف كنندكان

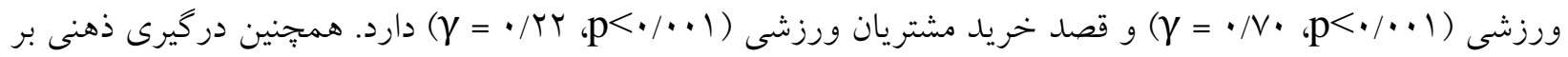

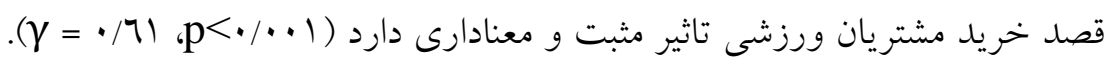

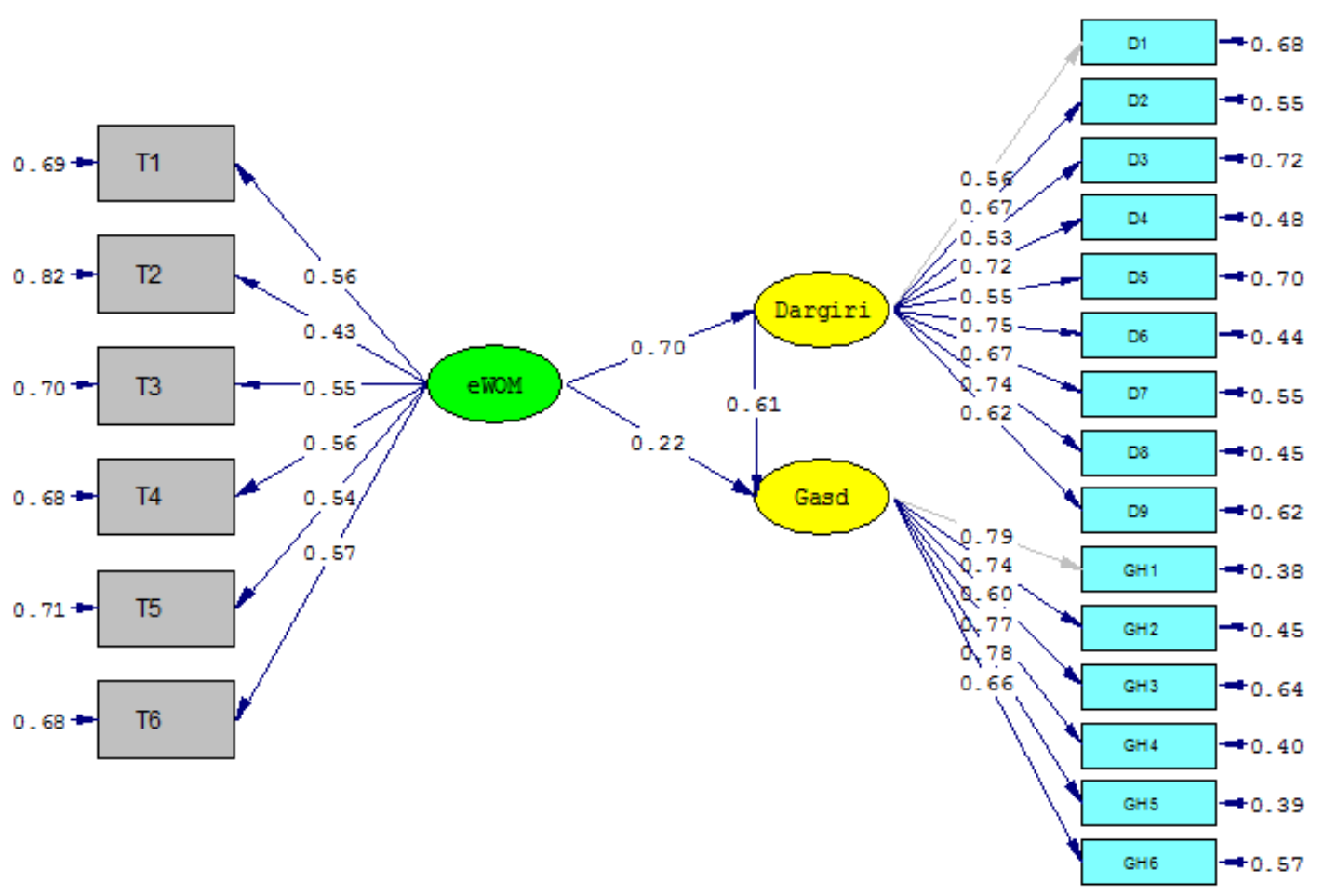

Chi-Square $=484.41, d f=186, P$-value $=0.00000$, RMSEA $=0.077$

شكل 1. ضرايب مسير مدل مفهومى يُّوهش در حالت تخمين استاندارد 


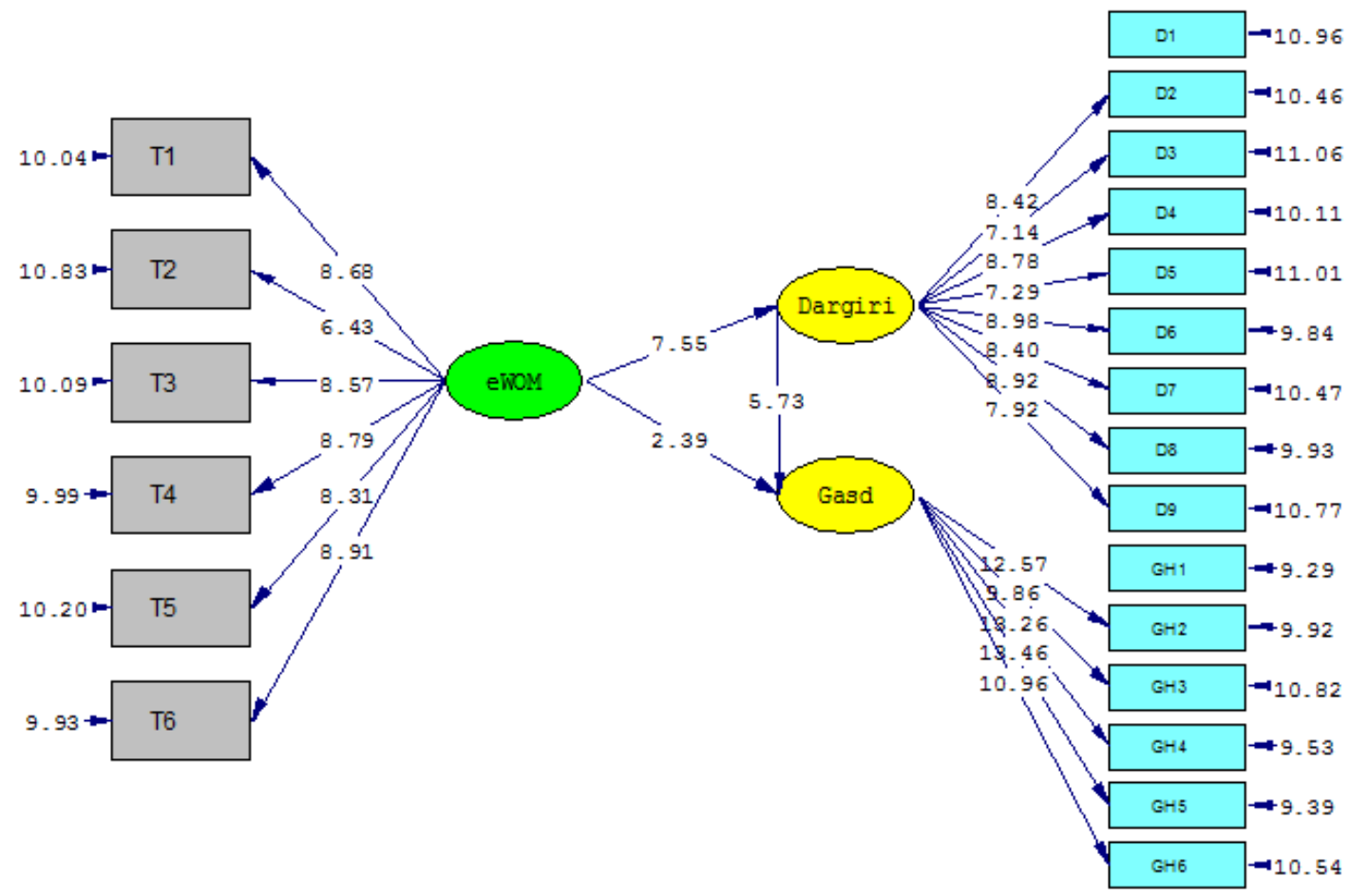

Chi-Square=484.41, df=186, P-value=0.00000, RMSEA=0.077

شكل r. اعداد معنادارى ضرايب ساختارى مدل مفهومى يزّوهش

جدول 0 اثرات مستقيم، غير مستقيم و اثر كلى متغيرهاى مدل تحقيق را نشان مى دهد. بررسى ضرايب مسير نشان مى دهد كه اثر مستقيم تبليغات دهان به دهان الكترونيكى بر قصد خريد مشتريان ورزشى كمتر از اثر غير مستقيم است (T/T/. در برابر بع/•). اثر مستقيم تبليغات دهان به دهان الكترونيكى بر درگيرى ذهنى مصرف كنندگان ورزشى بيشتر از قصد خريد مشتريان مى باشد (مقادير بتا به ترتيب برابر •V/ • و 70/•).

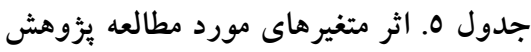

\begin{tabular}{|c|c|c|c|c|c|}
\hline \multicolumn{2}{|c|}{ در خيرى ذهنى } & \multicolumn{3}{|c|}{ قصد خريد } & \\
\hline 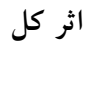 & مستقيم & اثر كل & غيرمستقيم & اثر مستقيم & \\
\hline$\cdot / v \cdot * *$ & $\cdot / v \cdot * *$ &.$/ 70^{* * *}$ & $\cdot /\left.\right|^{\mu * * *}$ & $\cdot \pi r^{*}$ & تبليغات دهانبهدهان الكترونيكى \\
\hline- & - & $\cdot / 71^{* * *}$ & - & $\cdot / 71)^{* * *}$ & درگيرى ذهنى مصرف كننده \\
\hline
\end{tabular}




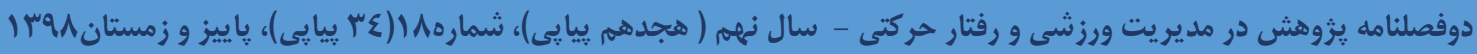

براى تحليل ميانجى گرى متغير درگيرى ذهنى در رابطه ميان تبليغات دهان به دهان الكترونيكى و قصد خريد مشتريان

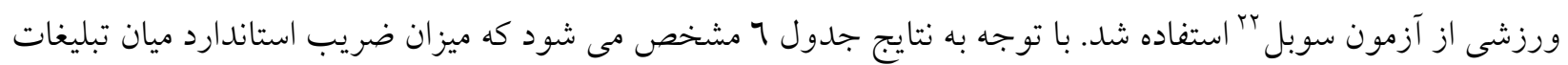
دهان به دهان الكترونيكى بر دركيرى ذهنى مصرف كننده برابر •V/ • با ميزان آماره t برابر V/00 مى باشد. براى بررسى

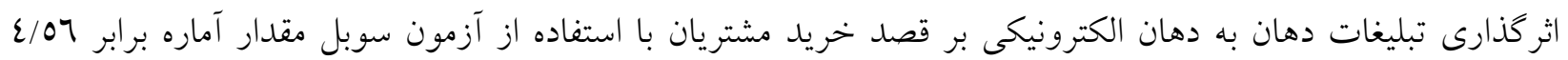
بدست آمد و ميزان ضريب استاندارد مسير غيرمستقيم برابر بع/• و اثر كل 70/• است. مقدار بدست آمده ضريب استاندارد مسير غيرمستقيم (سع/•) و ميزان آماره سوبل نشان دهنده اين موضوع است كه متغير دركيرى ذهنى بطور كامل نقش ميانجى را در ارتباط با تاثير تبليغات دهان به دهان الكترونيكى بر قصد خريد مشتريان لحاظ مى نمايد. جدول 7. بررسى نقش متغير ميانجى به روش آزمون سوبل

\begin{tabular}{|c|c|c|c|c|c|c|}
\hline نتيجه & غير مستقيم & سآماره آزمون & مقدار T T & ضريب استاندارد & جهت مسير & فرضيه \\
\hline \multirow[t]{2}{*}{ تاييد } & \multirow[t]{2}{*}{$\cdot / \varepsilon \pi$} & \multirow[t]{2}{*}{$/ 07$} & $V / 00$ & $\cdot N \cdot$ & تبليغات دهان به دهان الكترونيكى & \multirow{2}{*}{ 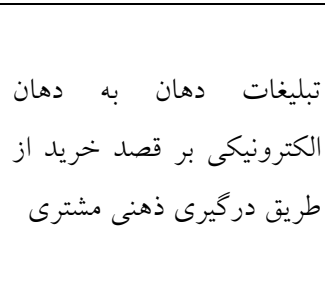 } \\
\hline & & & $O / N T$ & $\cdot / 71$ & دركيرى ذهنى بر خريد & \\
\hline
\end{tabular}

\section{بحث و نتيجه كيرى}

هدف يزوهش حاضر بررسى تاثير تبليغات دهانبهدهان الكترونيكى بر قصد خريد مشتريان ورزشى بود. نتايج نشان داد

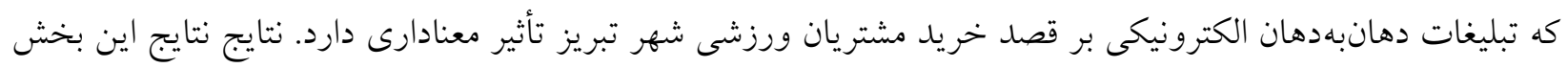

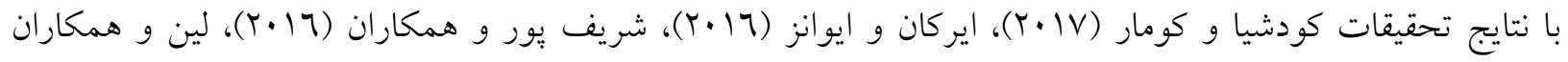

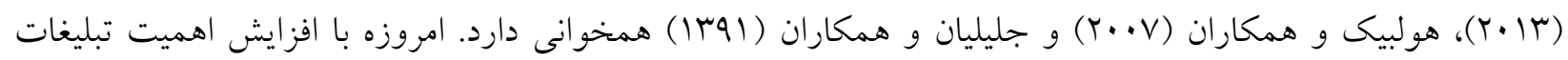
دهانبهدهان الكترونيكى بررسى رفتار مشتريانى كه در معرض اين نوع تبليغات هستند براى شركت ها و فروشگاههاى

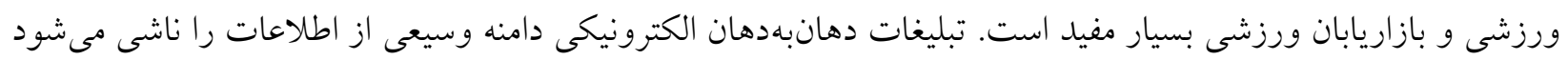
كه اين حجم زياد اطلاعات، مى تواند بر رفتار مصرفكننده در جهت آكاهى، انتخاب يكى برند يا محصول ورزشى و قصد

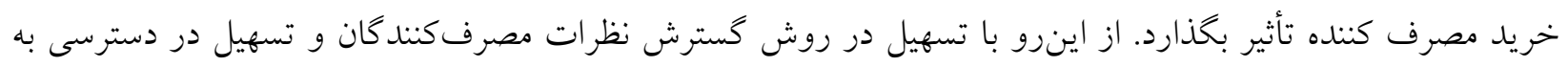
جنين نظراتى، وبسايت اينترنتى و شبكه هاى اجتماعى تأثير عميقى بر تصميمهاى خريد مصرفكنندهها دارند. توصيهها و نظرياتى كه مشتريان ورزشى در مورد تجربيات خريد و مصرف محصولات ورزشى خود طرح مى كنند مىتواند بر رفتار

22 - Sobel Test

https://jrsm.khu.ac.ir/ 


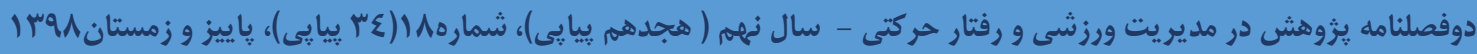

خريد و مصرفى ديخر تأثير زيادى بحذارد؛ بنابر اين تبليغات دهانبهدهان الكترونيكى بهعنوان شكلى از ارتباطات بازاريابى، بهرغم دشوارى كتترل اين كانال اطلاعاتى (صحت و سقم تبليغات محصولات) براى بازاريابان، واقعبينانه است و مىتواند بر ميزان فروش محصولات ورزشى تأثير زيادى بحذارد. با توجه به نتايج اين بزوهش مى توان به شركت ها و فروشكاههاى ورزشى بيشنهاد نمود كه با راهاندازى وبسايتها و كانال ها در شبكه هاى اجتماعى مختلف، مى توانند با معرفى و تبليغ محصولات ورزشى خود، امكان تبادل اطلاعات و تجربيات را براى مصرف كندكان خود فراهم آورند و بدين طريق با استفاده از تبليغات دهانبهدهان الكترونيكى، تجربيات رفتار يس از خريد مشتريان ورزشى را به ساير مشتريان بالقوه منتقل نموده و قصد خريد مشتريان بالقوه-كه در مرحله جستجوى اطلاعات و ارزيابى كزينه ها هستند- را افزايش دهند. نتايج نشان داد كه تبليغات دهانبهدهان الكترونيكى بر دركيرى ذهنى مصرف كنندگان ورزشى شهر تبريز تأثير معنادارى

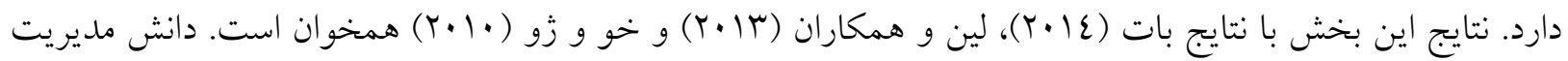
تبليغات و ارتباطات بازاريابى بهعنوان دانشى تخصصى كه هدف اصلى آن تأثير كذارى بر ذهن و رفتار مخاطب براى دستيابى به هدف هاى تجارى و غيرتجارى است. كاركرد تبليغات، كاركردى بسيار بييجيده است. اين دشوارى، در جخونخى

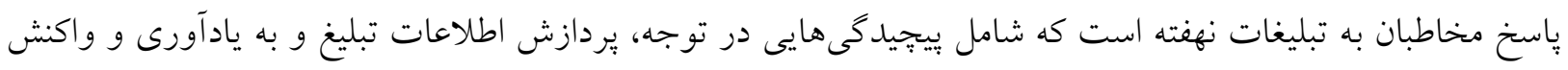
نسبت به جاذبههاى تبليغات توسط مخاطبان است. تبليغات بهعنوان يك ابزار بسيار مهم ترويجى بهحساب مى آيد؛ بهويزه براى شركتهايى كه در بازار مصرف براى فروش كالا و خدمات خود در تلاش و تكايو هستند. تبليغات مىتواند در خلق تصوير ذهنى برند و جاذبههاى نمادى يك شركت يا برند مفيد باشد. ازاينرو مىتواند بر دركير كردن ذهن مشتريان نسبت به خريد يك محصول تأثير كذار باشد. هر اندازه كه ميزان دركيرى ذهنى مشترى افزايش مىيابد، مصرفكنتدكان انخيزه بيشترى براى توجه، فهم و بازشكافى اطلاعاتى كه در خريد يك كالا مهم است به دست مى آورند. دركيرى ذهنى محصول قطعاً با آكاهى يا اطلاعات در مورد ويزگى هاى محصول، درى اهميت محصول، درى نام و نشان تجارى و ارجحيت آن، درى تبليغات و درى ريسك مصرفكننده، همراه است. براى افراد با دركيرى ذهنى بالا (تلاش بيشترى

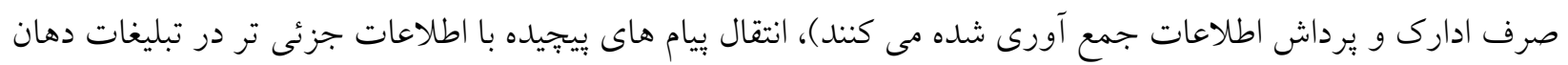
به دهان الكترونيكى ييشنهاد مى شود و در مقابل براى افراد با درگيرى ذهنى بايين تر (اطمينان بيشترى به جنبه هاى

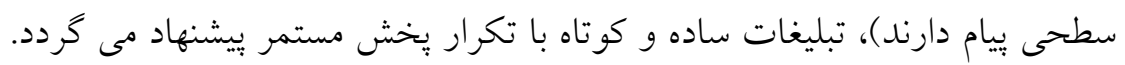
نتايج نشان داد كه تبليغات دهانبهدهان الكترونيكى از طريق متغير ميانجى دركيرى ذهنى مصرفكنند گان بر قصد خريد

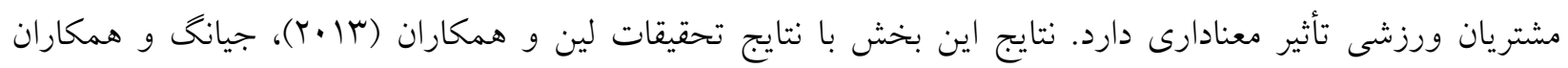

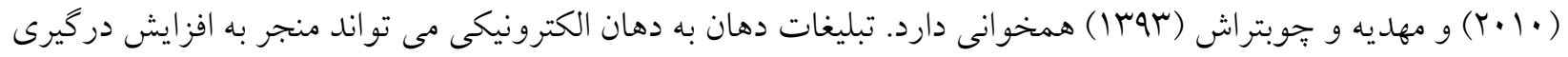
ذهنى مصرف كننده شود. مصرف كنند گان با دركيرى ذهنى بالاتر در مورد محصولات و جايكزينهاى متفاوت آن، فعالانه جستجو مى كنند. آنها منابع اطلاعاتى متفاوتى را جستجو و تلاشهاى آكاهانهاى را صرف جمع آورى اطلاعات مى كنند، يردازش اطلاعات عميقتر صورت كرفته و همجنين ارزيابى يس از خريد اين مصرف كنند گان سنجيدهتر و آكاهانهتر و 


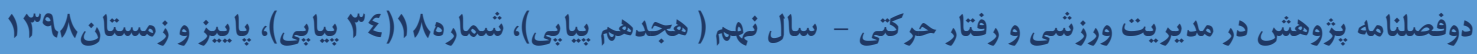

راضى و خشنود كردنشان بهمراتب دشوارتر است؛ بازاريابان نيازمندند كه تلاش بيشترى را صرف رضايت آنها نمايند،

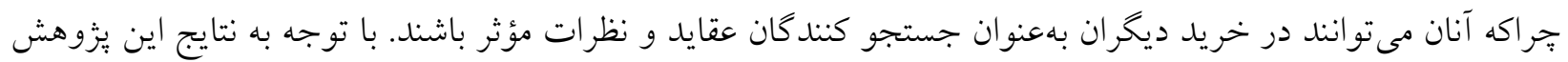
يّيشنهاد مى شود كه شركت ها و فروشگاه هاى ورزشى بايستى ارتباطات آنلاين مشترى به مشترى را جدى كرفته و از طريق تبليغات دهان به دهان الكترونيكى بعنوان يكى از ابزارهاى بازاريابى، ضريب نفوذ مزيت رقابتى كسب و كارهاى

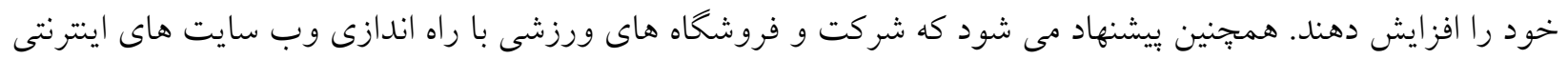
كه داراى ويز كى هاى لذات كرايانه (ايجاد هيجان، حس كنجكاوى، سهولت خريد، استفاده از طراحى جذاب، رنخ هاى متنوع، موسيقى و ويدئوهاى جذاب روى صفحات وب) و ويزگگى هاى نفع گرايانه (داراى محصولات متنوع تر، قيمت هاى ارزان، كيفيت بالاتر محصولات، اعتبار و اطمينان وب سايت، جستجوى منابع اطلاعاتى مختلف در مورد محصولات وب سايت، نظرات و تجربيات مشتريان در خصوص محصولات سايت) باشد مى توانند بر درگيرى ذهنى مشتريان تاثير مطلوبى ايجاد كرده و بدين طريق قصد خريد مشتريان آنلاين را افزايش دهند. در نتيجه گيرى يايانى مى توان گفت، با توجه به اينكه بازاريابى دهان به دهان الكترونيكى بر درگيرى ذهنى و قصد خريد مشتريان ورزشى تاثير مثبت و معنادارى دارد، لذا ضرورت دارد كه دركيرى ذهنى مصرف كننده همواره مدنظر بازاريابان ورزشى كه خواهان افزايش سودآورى خود از طريق افزايش قصد خريد مصرفكنندكان هستند، قرار كيرد. استفاده از بازاريابى دهان به دهان الكترونيكى و ارائه اطلاعات مفيد و نظرات و امتيازات مشتريان در مورد محصولات ورزشى مى تواند عاملى در افزايش دركيرى ذهنى مشتريان و خريد مجلد را در آنها ايجاد كند.

\section{تشكر و قدردانى}

مولفان بر خود وظيفه مى دانند از همكارى كليه تكميل كنند كان برسشنامه ها و همجنين تمام كسانى كه بصورت مستقيم يا غير مستقيم در انجام اين بزوهش، ما را يارى نمودند تشكر و قدردانى نمايند. 
1-Zahmatkesh, N. [The survey of effective factors Electronic Word of Mouth on costomer purchase intention (case study on Iran Insurance Company). (in Persian)]. [MSc]. Faculty Management and Accounting, Allameh Tabataba'i University, Tehran; 2015.

2- Zhang, Z. Ye, Q. Law, R. \& Li, Y. [The impact of e-word-of-mouth on the online popularity of restaurants: A comparison of consumer reviews and editor reviews]. International Journal of Hospitality Management, 2010; 29(4): 694-700.

3- Cakim, I. M. [Implementing word of mouth marketing]. New Jersey: Wiley; 2010.

4- Cheung, C.M.K. \& Thadani, D. R. [The impact of electronic word-of mouth communication: A literature analysis and integrative model]. Decision Support Systems, 54(1): 461-470.

5- Jalilvand, M.R. \& Samiei, N. [The Effect of electronic word of mouth on brand image and purchase intention: An empirical study in the automobile industry in Iran]. Marketing Intelligence \& Planning, 2012; 30(4): 460-476.

6- Zaichkosky, J. [Involvement]. Journal of Advertising Research, 2005; 15(2): 4-14.

7- Fournier, S. M. [Consumer and their Brands: Developing Relationship Theory in Consumer Research]. Journal of Consumer Research, 2010; 24(4): 343-373.

8- Heidarzadeh, K. \& Taghiporyan, M.J. [Typology of consumer involvement and their measurement modelings (in Persian)]. Bussiness Reviews, 2012; 53, 14-25.

9- Mahdieh, O. \& Chubtarash, N. [Consumer Involvement and Purchase Decision (Cell Phone as a Case Sstudy) (in Persian)]. Journal of Marketing Management, 2014; 9(22), 131-151.

10- Bhattacharya, D. \& Saha, D. [Consumer involvement profile incorporating the moderating effects of brand loyalty and brand trust]. Asia Pacific Journal of Marketing and Management Review, 2013; 2 (2); 23-45.

11-Verbeke, W. \& Vackier, I. [Profile and effects of consumer involvement in fresh meat]. Meat Science, 2004; 67(1): 159-168.

12- Butt, A. [The relationship between Purchase Intention and Product Involvement: The role of Brand Attitude as a mediator on this relationship]. Paper presented at the Proceedings of International Academic Conferences; 2014.

13- Lin, C. Wu, Y. S. \& Chen, J.C. V. [Electronic word-of-mouth: The moderating roles of product involvement and brand image]. TIIM 2013 Proceedings, 39-47; 2013.

14- Xue, F. \& Zhou, P. [The Effects of Product Involvement and Prior Experience on Chinese Consumers' Responses to Online Word of Mouth]. Journal of International Consumer Marketing, 2010; 23(1): 45-58. 14

15- Jiang, Z. Chan, J. Tan, B.C.Y. \& C, W.S. [Effects of Interactivity on Website Involvement and Purchase Intention]. Journal of the Association for Information Systems, 2010; 11(1), 34-59.

16-Kudeshia, C. \& Kumar, A. [Social e-WOM: does it affect the brand attitude and purchase intention of brands?] Management Research Review, 2017; 40(3): 310-330.

17-Erkan, I. \& Evans, C. [The influence of e-WOM in social media on consumers' purchase intentions: An extended approach to information adoption]. Computers in Human Behavior, 2016; 61: 47-55.

18-Sharifpour, Y. Sukati, I. \& Alikhan, M. N. A. B. [The Influence of Electronic Word-of-Mouth on Consumers' Purchase Intentions in Iranian Telecommunication Industry]. American Journal of Business, 2016; 4(1): 1-6.

19- Hollebeek, L. D. Jaeger, S.R. Brodie, R.J. \& Balemi, A. [The influence of involvement on purchase intention for new world wine]. 2007; Food Quality and Preference, 18: 1033-1049. 
20- Jalilian, H. Ebrahimi, A.H. \& Mahmoudian, O. [The Effect of Electronic Word of Mouth (e-WOM) on Consumer's Purchase Intention through Customer Based Brand Equity (CBBE) )The Case: Dell Laptop (in Persian). Journal of Business Management, 2013; 4(14), 41-64.

21- Sahabi Yusuf, A. Che Hussin, A.R. \& Busalim, A.H. [Influence of e-WOM engagement on consumer purchase intention in social commerce]. Journal of Services Marketing. 2018; 32(4): 493-504, https://doi.org/10.1108/JSM-01-2017-0031

22- Bambauer-Sachse, S. \& Mangold, S. [Brand equity dilution through negative online word-of-mouth communication]. Journal of Retailing and Consumer Services, 2011; 18; 38-45.

23- Khalili Roudi, M. [Effect of involvement and personality traits on clothing impulsive purchase decision (in Persian)]. [MSc]. Faculty Management and Accounting, Allameh Tabataba'i University, Tehran; 2015.

24- Diallo, M. F. [Effects of store image and store brand price-image on store brand purchase intention: Application to an emerging market]. Journal of Retailing and Consumer Services, 2012; 19: 360-367.

25- Park, H. J. Rabolt, N. J. and Jeon, K. S. [Purchasing Global Luxury Brands among Young Korean Consumers]. Journal of Fashion Marketing and Management, 2008; 12(2): 244-259.

26- Bakhshizade, K. Khalili Roudi, M. \& Rezaiean Akbarzadeh, S. [Impact of personality traits and product involvement on clothing impulsive buying (in Persian)]. Journal of Business Management, 2016; 8(1), 29-46.

27- Saeida Ardekani, S. \& Jahanbazi, N. [Influence of store image on purchase intention: The moderating role of trust and perceived risk. (in Persian)]. Journal of New Marketing Research, 2015; 5(2), 53-72.

28- Angoori, P. \& Sheikhalizadeh, M. [The effect of brand equity on customer repurchase intention of Majid sporting goods (in Persian)]. Paper presented at the 10th International Congress on Sport Sciences. 26-27 April 2017, Tehran, Iran; 2017.

29- Davari, A. Rezazadeh. [A. Structural equation modeling with PLS (in Persian)]. Tehran: Jahad Daneshgahi, 2013.

30- Nunnally J. C, Bernstein I. H. [Psychometric Theory]. McGraw-Hill, New York; 1994.

31- Kline, P. [An Easy Guide to Factor Analysis]. Translate by Seyes Jalaledin Sadrossadat and Asgar Minaei, Samt Publication, Tehran; 2001.

32- Barclay, D. Higgins, C. \& Thompson, R. [The Partial Least Squares (PLS) Approach to Causal Modeling: Personal Computer Adoption and Use as an Illustration]. Technology Studies, 1995; 2 (2), 285-309. 